\title{
Violence in the Christian Bible: Assessing Crossan's use of 'violence' as a key analytical concept
}

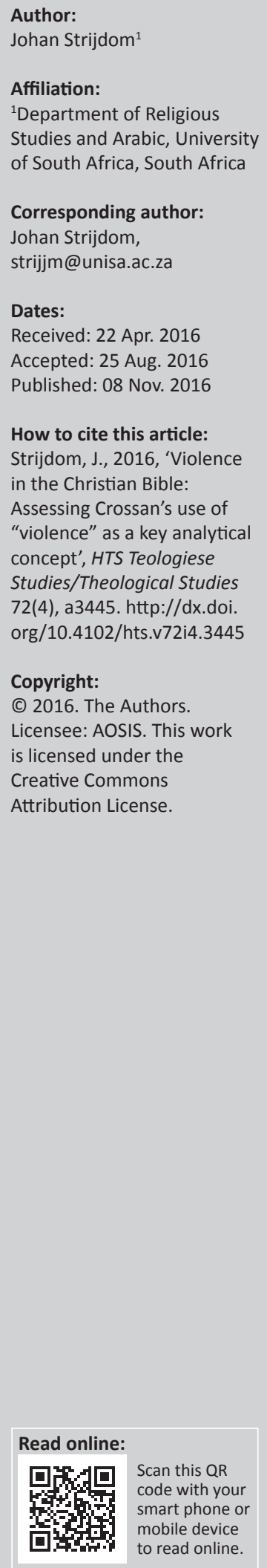

In this article Crossan's analysis of violence in the Christian Bible is assessed by means of two overlapping strategies. The first strategy takes seriously the insistence by scholars of comparative religion that the application of theorised key concepts to case studies may throw new light on an issue. By taking David Chidester's mapping of definitions and theories of the concept of 'violence' as a point of reference, Crossan's conceptualisation of violence in the Bible is assessed. Secondly, Burton Mack's critical application of Girard's theory of violence to early Christian myth formations and their legacy in the West is compared with and used to assess Crossan's analysis. In conclusion, the imperative to reflect further on the ethical question of violence is highlighted.

\section{Introduction}

In his recent book How to read the Bible and still be a Christian: Struggling with divine violence from Genesis through Revelation, John Dominic Crossan (2015) analyses the concept of violence in the Christian Bible. As one of the most prominent late 20th and early 21st century researchers on the historical Jesus and early Christianity, ${ }^{1}$ his reading of biblical texts is informed by a historicalcritical and intertextual approach that insists on interpreting these texts within their original social, political and economic contexts as a necessary prelude to the question of their relevance for today. In this recent book, Crossan (2015) argues that violent and non-violent visions are in dialectic interaction from the beginning to the end of the Christian Bible and proposes that Christians take his construct of a non-violent historical Jesus as normative in deciding between these visions.

In the field of Religious Studies, scholars have in the past two decades increasingly emphasised the importance of key terms for the academic study of religion. Not only have several reference works with key words been published (e.g. Braun \& McCutcheon 2000; Morgan 2008; Plate 2015; Segal \& Von Stuckrad 2015; Taylor 1998), but in-depth arguments have also been made on the importance of key concepts for the study of religion. J.Z. Smith (2004a), for example, has argued that native or first-order categories are mostly useless for analytical purposes, whereas the construction of second-order categories is imperative to create maps or models that will help us to analyse and shed new light on the territory that we study. ${ }^{2}$ David Chidester (2013) has similarly insisted that our best hope for producing innovative knowledge about religion(s) may depend on the application of theorised key concepts to religious case studies. ${ }^{3}$

Taking seriously this argument of scholars of religion that the application of theorised key concepts to our data may produce new knowledge about religion and religions, ${ }^{4}$ I clarify and

$$
\text { 1.For a biographical survey, publications and academic awards, see http://www.johndominiccrossan.com (viewed } 1 \text { April 2016). }
$$

2.Smith prefers the terms 'first-order' (or 'native') and 'second-order' to 'emic' and 'etic', although he did write the entry for 'emic' and 'etic' in the HarperCollins Dictionary of Religion and defined the terms as follows: 'a distinction between an act of cultural understanding 'etic' in the HarperCollins Dictionary of Religion and defined the terms as follows: 'a distinction between an act of cultural understanding
by the actors themselves (emic) and an understanding of that culture by trained outsiders (etic)' (Smith 1995; cf. also Smith 2004a:134, by the actors themselves (emic) and an understanding of that culture by trained outsiders (etic)' (Smith 1995; cf. also Smith 2004a:134,
$175,204,208,221,398)$. With reference to Hobbes, Smith (2000:35) holds 'the giving of names to names' as a scientific 'second-order activity' and 'the naming of things' as a utilitarian 'first-order activity'. An example would be the Bakiri of Brazil, who 'have names for each sort of parrot or palm' (native or first-order or emic categories) but have 'no word for the genus parrot or palm' (second-order or etic categories useful for mapping the territory and analysing the data).

3.Chidester has consistently emphasised this point in his writings. In his critique of the study of religion in South Africa, Chidester (1988) maintains that key terms need to be problematised theoretically and clarified in order to be useful for analytical purposes. In his review of Taylor's Critical terms for Religious Studies, Chidester (2000b) holds that not every term in that volume is of equal analytical value and argues that the application of theorised material terms to religious data offers a step forward in the comparative study of religion. Below I relate Chidester's conceptualisation of violence to Crossan's analysis.

4.'Religion' and 'religions' as analytical terms have been debated extensively in Religious Studies, with 'religion' seen as the genus and individual 'religions' as the species. J.Z. Smith $(2000,2004 \mathrm{~b})$ is well known for his statement that 'religion' is a generic category constructed by academics for analytical purposes. Chidester (2000b:373-374, cf. also 2000a, 1996 \& 2014), in reaction to Smith, argues that the category of 'religion' was not only created within colonial contexts but also used in imperial religious studies to justify the West's civilising mission to its colonies. Although Smith (2004b:174) emphatically acknowledges the term's colonial history (but the West's civilising mission to its colonies. Although Smith (2004b:174) emphatically acknowledges the term's colonial history (but
not sufficiently its use in imperial religious studies), he insists that we still need it as a category for analytical purposes. Some scholars of religion today opt for a narrow definition of 'religion' as linked to gods and spirits. Many, however, adopt and adapt the sociologist Emile Durkheim's broader functionalist definition, according to which 'religion' refers to beliefs (myths and doctrines) and practices 
assess Crossan's use of 'violence' as a key concept for analysis. If 'violence' is the issue that Crossan intends to analyse, how does he define and theorise about this concept in his analysis? I ask whether Chidester' $\mathrm{s}^{5}$ conceptualisation of 'violence' may help us here. ${ }^{6}$ I also relate Crossan's analysis to that of Burton Mack $^{7}$ as a historical-critical scholar of early Christianity, who has offered a theoretically informed analysis of violence in the case of the Christian canon. However, before we engage Crossan on this key term, we first need to follow his argument closely.

\section{Crossan's analysis of violence in the Christian Bible}

In his analysis of violence in the Christian Bible, Crossan offers us a historical-critical and intertextual reading of a selection of texts from this corpus on the theme of violence. Not only does he interpret these texts within their original social-political-economic historical contexts, but he also relates them critically to the pressing issue of violence that Christians must deal with and take a stance on in today's world. His argument in essence is that in these texts from Genesis to Revelation, violent and non-violent visions do not simply alternate with each other but are in dialectical interaction. In the end, Christians today must decide which of the two visions they would follow. In Crossan's view, his construct of the historical Jesus with his vision of non-violent, distributive justice should be the normative criterion for Christians. ${ }^{8}$

\section{Violence and non-violence in Genesis 1-9}

Crossan (2015:41-57) begins with the Garden of Eden and interprets this narrative within a Mesopotamian matrix. Instead of reading Genesis 2-3 through its later Christian interpretation as the fall of humanity, original sin and divine punishment, he instead analyses this creation story through the lens of the epic of Gilgamesh. Seen in this way, both Genesis 2-3 and Gilgamesh focus on mortality as the inevitable

(footnote 4 continues...)

(rituals) relative to the sacred (i.e. things set apart) that serve to bind adherents together as a unified community. Social theorists of religion emphasise that religion is not separate from secular politics as modernity has claimed but that religion is embedded in society, politics and economics. Critical theorists, furthermore, in response to functionalists, highlight the conflictual potential of religion in sustaining asymmetrical power relations of class, gender, race, imperialism, nationality and so on.

5.For Chidester's publications and academic awards, see http://www.religion.uct. ac.za/religion/staff/academicstaff/davidchidester (viewed 1 April 2016).

6.A second key term that needs assessment is 'canon'. Because Crossan deals with the Christian Bible, how does he conceptualise 'canon' as a key term in his analysis? J.Z. Smith's (2004a, 2009) theory of 'canon' as a cross-cultural category and Burton Mack's (1995, 2008b) critique of the New Testament canon as the Christian myth Mack's (1995, 2008b) critique of the New Testament canon as the Christian myth
and its legacy may serve as points of comparison here. In this article I limit myself to the concept of violence.

7.For an appreciation and assessment of Mack's legacy (particularly his engagemen with social theories of religion), see the recent review essay roundtable by Sanchez (2015:826-857), as well as Rollens (2013:171-176).

8.Crossan (2015:237-246) uses three metaphors to think about the relationship between violence and non-violence in the Christian Bible. At the surface level on may imagine violence and non-violence as two separate train tracks running paralle may imagine violence and noralle throughout the Bible. At a deeper level one may think of them as a heartbeat, with unjust, oppressive and dominating systemic violence for victory through force on the one hand and just, distributive non-violence for peace through persuasion on the other hand constantly alternating and interacting with each other in 'a rhythmic sequence throughout the Bible. At the deepest level, however, icon presents itself as the most apt metaphor to Crossan for his proposal of a non-violent historica Jesus as the normative point on which Christians should focus their vision. human fate. After the death of his beloved friend Enkidu, Gilgamesh searches for immortality, learns from Utnapishtim (the flood hero who, along with his wife, was granted immortality by the gods) that eating a special plant located in the fresh water deep under the earth will give him eternal rejuvenation, finds the plant but loses it on his way home when a snake carries it off. He eventually dies like all human beings, never to rise again - as the gods had already warned him would happen. In Genesis 2-3, Adam and Eve are created by God in a well-watered garden in Mesopotamia. In the middle of the garden there are two trees: the tree of life and the tree of the knowledge of good and evil. Eating from the first tree will give them eternal rejuvenation. Like Mesopotamia, but unlike Egypt, Israel resisted for most of its ancient history the idea of eternal life by accepting death as the inevitable destiny of all human beings. It is, however, the introduction of the second tree, Crossan (2015:54-56) argues, that reveals the special adaptation by Israel and original intention of the author of Genesis 2-3: deciding to eat from the second tree gave humans moral conscience, the ability to distinguish between good and evil. This attainment of moral awareness as the consequence of human choice rather than divine punishment, Crossan (2015:56) concludes, was the original point of the creation story in Genesis 2-3.

Sin characterised as fratricidal violence is first introduced in the Bible as we move out of the Garden of Eden to Genesis 4. Within the context of the Neolithic agricultural and urban revolution, violence escalates exponentially in Genesis 4, beginning with the farmer Cain killing his shepherd brother Abel, then the threat of sevenfold vengeance if anyone murders Cain, and ending five generations later with the threat of a 77 -fold vengeance should the urban-dweller Lamech be killed. On Crossan's reading the focus here is still on human consequence rather than divine revenge: sin crouches like a feline ready to attack Cain at the tent flap, but guided by moral conscience he can overcome it (Gn 4:7). Cain instead willingly murders his brother in his field, and the bloodstained ground itself, rather than God, exiles him. Similarly, small-scale families in an honour and shame Neolithic civilisation engage in blood feuds of exponential vengeance for the killing of the agricultural Cain up to the urban Lamech. There is no divine retribution here, only human consequence. There is no human inevitability here to commit violence, only human choice to do so and the possibility to choose to overcome sin as violence.

Divine violence, however, enters with the story of the flood. In the Mesopotamian story the gods decide to destroy humanity on account of the noise caused by their increasing numbers, but in Genesis 6 the Priestly tradition ${ }^{9}$ gives human violence ('the earth filled with violence') as the reason for God's massive retribution against humans, animals and earth. God, Crossan $(2015: 70,72)$ states, has

9.Crossan (2015:69) accepts as 'general scholarly consensus' the distinction between four layers or sources in the Pentateuch: the Yahwist from about 950 BCE, the Elohist and Deuteronomist from about $850 \mathrm{BCE}$ and the Priestly tradition from Elohist and Deuteronomist from about $850 \mathrm{BCE}$ and the Priestly tradition from
about $500 \mathrm{BCE}$. He emphasises that later layers took up earlier ones and edited them to create a final whole. 
thus become 'sucked completely into humanity's escalatory violence', 'a God ... far worse than our worst evil'. However, hope then comes from God promising to " never again" ... undertake such divine terrorism' against earth because of human violence (Crossan 2015:71). This undertaking is made into a covenant between God and all living creatures with the rainbow as its visible sign in Genesis 9 - a unilateral and unconditional covenant, which in this Priestly tradition states 'never again' rather than 'never again, unless ...' (cf. Crossan 2015:83).

To give content to the character of this God, Crossan offers a comparative reading of Genesis 9 and Genesis 1, with recreation and covenant in Genesis 9, and creation but no covenant mentioned in Genesis 1. Both are from the Priestly tradition, but by deciding to open the Torah with this creation story the Priestly editors underlined its importance for understanding what was to follow. In Genesis 1 humans are not only created in the image or likeness of God to rule over or manage creation, but the story culminates in the Sabbath rest as the end and goal of creation. The God of the Priestly tradition is a 'Sabbath God' (Crossan 2015:77), who provides the model for his followers on how to manage the world. The exact meaning of 'Sabbath' is clarified elsewhere in the Torah:

- On the Sabbath day, every 7th day of the week, all humans, including children, slaves and immigrants, as well as domestic animals, should rest from their labour in order to be refreshed - equally without discrimination.

- In the Sabbath year, every 7th year, slaves should be freed, debts remitted and agricultural fields not sown, with slaves, labourers, domestic and wild animals allowed to freely eat the yield from these fields.

- In the Sabbath Jubilee, every 50th year, rural holdings alienated due to debt should be restored to their original owners, articulating the ideal of a God of distributive justice, which stood in contrast to the reality of accumulation of land and exploitation of the poor by the wealthy.

Compared to the creation of Genesis 1, the re-creation of Genesis 9 is surely less benign: the managers of creation may now eat animals except for their blood, whereas in Genesis 1 humans and animals are vegetarian by eating only the plants that God gave them; God also now in Genesis 9:6 allows humans to take vengeance in blood feuds, but indicates that humans will be responsible for the consequences of that choice.

Most important to note is the addition of the term covenant in Genesis 9 that is not mentioned in Genesis 1. Here in Genesis 9 it is presented as a unilateral and unconditional covenant from God. According to scholarly consensus, Crossan (2015:86) holds, Israel adopted and adapted Anatolian treaties between Hittite suzerain and subject vassal kings that spread throughout the ancient Near East as a model for imagining their or the world's relationship with God. In these bilateral, hierarchical contracts, sworn before the gods and cosmic forces as witnesses, ${ }^{10}$ and serving the interests of the imperial power to control its colonial subjects (cf. Crossan 2015:87), legal stipulations constituted the heart of the treaties. Motivation for the subject kings to keep to the commitments was based in the treaty on the one hand on account of what the suzerain had done for the vassal in the past. On the other hand it was based on curses threatening future divine punishment against the vassals for breaking the legal stipulations of the contract and blessings promising future divine rewards for keeping them (no curses are, of course, listed against the suzerain, should he break his commitments).

\section{Violent and non-violent covenants}

If there is no mention of divine threat and curses in the Priestly tradition of Genesis 1's creation as well as Genesis 9's re-creation (where the covenantal promise of 'never again' is unconditional), the content of covenant is imagined very differently in the Deuteronomic tradition - a tradition that Crossan (2015:119) considers a 'crime against both divinity and humanity'. In the Deuteronomic tradition, curses and fear of future punishment rather than history dominate as motivation for keeping the legal stipulations of the covenant, as is clear from the closing chapters of Deuteronomy 27-30. This negative view of a covenantal God of violence, Crossan (2015:89-99) argues, is due to the influence of 8th and 7th century BCE Assyrian treaties.

Unlike the Hittite treaties that focused on what the suzerain had done for the vassals in the past, and that included evenly balanced curses and blessings for the future, as motivations for keeping the covenant, the treaties of the much more brutal Assyrian Empire did not include a section on their beneficial actions for the vassal in the past, but multiplied curses and intensified threats of divine punishment not only against subject kings but also explicitly against their populations, should they not keep the commandments. They, furthermore, had their subjects participate ritually in their own potential destruction should they break their exclusive loyalty to the Assyrian Empire - an exclusive loyalty that is reflected in the Deuteronomist's monotheism, which demanded love for one God only. Too much of the god Ashur of Assyria, Crossan (2015:94) concludes, entered the Deuteronomist's view of Israel's God. The Deuteronomic covenant unfortunately came to be modelled too much on terrifying Assyrian-style treaties.

Because the Deuteronomic vision of covenant was not always evident in empirical history, authors had a choice either to rewrite history to conform to Deuteronomic theology

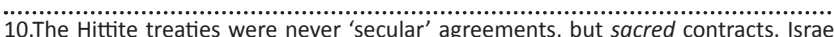
too imagined their covenant with God as 'a religio-political, religio-social, and religio-economic commitment between God and the world as macrocosm or God and Israel as an experimental microcosm' (Crossan 2015:86). The superior-toand Israel as an experimental microcosm' (Crossan 2015:86). The superior-tosubordinate relationship between God as suzerain and Israel as vassal is clear. It is reflected, for example, in the preamble to the covenant in Joshua 24:2: 'Thus says the Lord, the God of Israel' (Crossan 2015:84). The history of what God has done for Israel is then presented at length as motivation to keep the covenant before the covenant is renewed and legal obligations are fixed in Joshua 24. The stipulation of legal ordinances demanding certain actions and forbidding others as the core of the covenant is detailed, for example, in the 'covenant code' of Exodus 20-23 (Crossan 2015:85). 
or to rethink that theology. For example, confronted in 2 Kings 21 with the bad king Manasseh, who lived a long life, and in 2 Kings 23 with the good king Josiah, who was killed too early in battle, the Chronicler decided to rewrite his sources to fit Deuteronomic theology: the bad king Manasseh is now in 2 Chronicles 33 said to have repented and thus to have deserved his long life, whereas the good king Josiah in 2 Chronicles 35 is said to have been unfaithful to God by not listening to the words of God spoken through the king of Egypt and was therefore killed in battle as divine punishment.

The 4th-century book of Job, however, offered a radical challenge to the Deuteronomic view of covenant by rethinking that theology. In Job 3-37 we hear Job's friends, 'by-the-book Deuteronomists, or Deuteronomic fundamentalists' (Crossan 2015:98), telling Job that his sufferings were from God, punishing him for sins that he had committed, but this Deuteronomic theology is then exposed as bad and false to hearers and readers as God negates its validity at the beginning (Job 1:8) and end (Job 42:7) of the book. Job should have served " $[t]$ o stultify the Deuteronomist / And change the tenor of religious thought"' (quoting Robert Frost), but 'sadly', Crossan (2015:98) remarks, 'the book of Job was but a speed bump on the Deuteronomic superhighway'.

The prophetic tradition, for all its courageous insistence on God's distributive justice, often against the abuses of royal power, also consistently in a Deuteronomic vein threatened Israel with God's violent retribution for failing to adhere to the distributive demands of the covenant. Crossan (2015:101-110) uses the 8th to 7th century BCE prophet Isaiah (in Is 1-39) under the brutal Assyrian Empire as representative case study to illustrate his problem with a violent God in the prophetic tradition. Isaiah imagines God as king enthroned in his heavenly court and surrounded by angels as his courtiers. From here he rules and judges. The prophet in ecstatic altered state of consciousness in that heavenly court is in the privileged position of seeing and hearing God's accusation and prosecution of Israel for transgressing the covenantal laws and is officially sent to carry and interpret the divine message to Israel. The model is taken from the Assyrian imperial court in Nineveh: the Assyrian king accuses, judges, condemns and punishes a rebellious vassal. Similarly, the suzerain God brings his complaint against his rebellious vassal Israel (cf. Is 1). Just as the Assyrian king uses an official messenger to deliver and interpret his message to the vassal king as well as the subject people, so does God in sending his prophet to Israel. The major difference, of course, is that whereas the Assyrian messenger represents the Assyrian king from his earthly court, the Hebrew prophet represents the God of Israel who speaks about the king of Assyria from his heavenly court. We are thus urged to scrutinise the content of the prophetic vision. In Isaiah 1, Judea's devastation by Sennacherib is explained by the prophetic messenger as God's legal condemnation, curse and punishment for their breaking of the covenant's demand for systemic social justice. Because Israel neglected to do good to the vulnerable ones in society, God is said to have accused, judged, condemned and punished them most violently through the military terror of imperial Assyria as his agent (In Is 10).

Crossan (2015:110) insists that both aspects should be emphasised in the prophetic tradition: God's insistent demand for equitable distribution of resources, but also 'an equally insistent threat of divine retributive justice ... for maldistribution'. It is, however, this latter aspect that Crossan finds deplorable. With tiny Israel squeezed in between warring empires on all sides, 'invasion for Israel was inescapable and defeat inevitable - despite Deuteronomy 28 '. He concludes, to repeat:

It is a crime against both humanity and divinity to tell people so located that a military defeat is a punishment from God. This holds also, but for different reasons, on disease and drought, famine and even earthquake ...

External invasions, internal famines, and other disasters were not divine punishments for how the people of Israel lived its covenantal life with God, but human consequences of where the nation of Israel lived it (Crossan 2015:118-119).

\section{Violence and non-violence in the Psalms and Wisdom tradition}

Turning to the Psalms, Israel's 'prayer book', Crossan (2015:110-111) notes the same ambiguity. On the one hand, creation is celebrated as 'God's original act of distributive justice' and his concern for the vulnerable ones in society is repeatedly praised (e.g. Ps 146). Psalm 8, as a rephrase of Genesis 1, particularly stands out for celebrating humans as responsible for managing God's creation. On the other hand, Israel is haunted by the fear of breaking the covenant, which in Deuteronomic theology would unleash God's anger against them. In the Psalms they therefore not only repeatedly invoke God's promise to keep the covenant forever, even if they fail, but also repeatedly plea for God's individual and collective forgiveness and mercy - pleas that in Crossan's (2015:113) view mar the first vision that stresses human consequences and the possibility of human change in collaboration with God before it is too late, rather than divine punishment and divine mercy.

The Wisdom tradition, within a 4th to 3rd century BCE Egyptian Hellenistic matrix of scribal schools training learned retainers as administrators for palace and temple, elaborates in Crossan's (2015:122-126) reading on the vision from Genesis 1 and Psalm 8. In Proverbs, Sirach and Wisdom of Solomon (the latter two books admittedly not accepted by all Christians as part of the canon), Wisdom is portrayed not only as a 'personified process', who constituted the medium through which God created everything, but also 'as a philosopher walking the city streets in search of willing students' (Crossan 2015:122). On the one hand, through proverbs and aphorisms, these learned teachers domesticated the radical vision of systemic change for distributive justice by instead promoting a personal and individual ethics of liberal charity for vulnerable ones. On the other hand, their vision of a non-violent God from Genesis 1, is in Crossan's (2015:126) judgement 'a profound breakthrough', with its 
emphasis on human responsibility, moral conscience and the consequences of human choice rather than external divine punishment.

It is high time, he concludes again, now with reference to the Psalms and Wisdom tradition, that 'we rethink both the theory of divine punishment and the resultant practice of pleading for forgiveness and crying out for mercy' and instead 'begin, aside from natural disasters and random accidents, to accept fully the human consequences for what we do' (Crossan 2015:126).

\section{Violence and non-violence in Daniel's apocalyptic vision and contemporary literature}

Bringing us closer to the time of Jesus, Crossan (2015:127-138) analyses the apocalyptic vision in Daniel 7 as an example of the kingdom tradition. Composed in the 160s BCE under the religio-political persecution of Antiochus IV Epiphanes' Syrian Greek empire, the book of Daniel is fictionally located in the 6th to 5th century BCE transition from the Babylonian to Median-Persian empires. In Daniel 7, Daniel sees in a night vision four successive empires before the arrival of the kingdom from God. The first three empires of Babylonia, Media and Persia are symbolised as wild beasts arising from the sea, whereas the fourth beast is not identified with a wild beast but is simply said to be extremely terrifying and utterly destructive. God, enthroned as king in his heavenly court and surrounded by his angelic hosts, judges and condemns these empires, especially the Greek Syrian empire. Daniel then sees someone like a human being (i.e. someone unlike the preceding beasts) coming with the clouds from God. This humanlike one is the archangel Michael, to whom God gives his kingdom, who again hands it over for protection to the angelic hosts, who will eventually bring it down from heaven to earth as a gift to Israel.

With tiny Israel living precariously between warring empires, this hope for a just world replacing unjust empires here on earth was not an invention of Daniel but had formed part of Israel's tradition for more than 500 years before Daniel's era even if terms other than 'kingdom' were used. If Daniel's vision is not explicit about the exact nature of God's kingdom, other authors give us a fuller description. Micah and Isaiah from the 8th century BCE imagined a peaceful earth from God, where:

(peoples) shall beat their swords into plowshares,

and their spears into pruning hooks;

nation shall not lift up sword against nation,

neither shall they learn war anymore;

but they shall all sit under their own vines and under their own fig trees,

and no one shall make them afraid (Mic 4:3-4 = Isa 2:4, quoted in Crossan 2015:135).

Egyptian Jews in the Sibylline Oracles from the same time as Daniel imagined this last kingdom as not only free of violence but also as one in which wealth would be distributed justly. An updated version of the Sibylline Oracles from around the time of Jesus details the content of this hope for a just system from God, for a world of universal peace through distributive justice, as follows:

The earth will belong equally to all, undivided by walls or fences ... Lives will be in common and wealth will have no division. For there will be no poor man there, no rich, and no tyrant, no slave. Furthermore, no one will be either great or small anymore. No kings, no leaders. All will be equal together (Sibylline Oracles 2.319-324, quoted in Crossan 2015:138).

\section{The historical Jesus, Gospels and Revelation on violence and non-violence}

We have now arrived at the time of the historical Jesus, a Jewish peasant who lived in early 1st-century rural Galilee under the Roman Empire, whose vision and programme of God's kingdom should, in Crossan's view, provide for Christians the normative criterion in deciding between the non-violent distributive and violent retributive alternatives presented in the Bible.

To the reality of the Roman Empire, Jews in the Jewish homeland could respond in various ways: they could choose to collaborate (as many retainers and especially wealthy aristocrats did) or to resist imperial religio-politicaleconomic oppression. If the latter, they could do so violently by taking up arms against Rome. Alternatively, they could resist non-violently - for example, when Caligula around 40 CE attempted to have his statue erected in the Jerusalem Temple, many went on a huge unarmed agricultural strike, willing to accept collective martyrdom if necessary. However, we also need to ask whether non-violent resistance involved human non-violence but imagined apocalyptic divine violence, or whether the non-violent vision applied to humans and God alike. If it was hoped that God would establish his just rule on earth through an earthly or angelic Messiah or Christ, in Crossan's view we need to ask whether that intermediary was imagined to be violent or non-violent.

Within those possibilities of resistance, Crossan locates the historical Jesus' kingdom movement among the non-violent options of resistance to Roman violent oppression and exploitation. It involved neither human violence nor imagined apocalyptic divine violence. Herod Antipas, the tetrarch client king of Rome in lower Galilee, built the new capital Tiberias around $20 \mathrm{CE}$ in honour of the Roman emperor on the lake of Galilee and monopolised and commercialised its fish industry to increase his tax base, pushing its fishermen into poverty. Against this programme, in the late 20s CE, Jesus proclaimed an alternative vision through parables and aphorisms and enacted an alternative programme by reaching out to vulnerable ones and encouraging Galilean villagers and impoverished fishermen to collaboratively share their resources among each other.

Unfortunately, this vision changed as the non-violent historical Jesus became increasingly reinterpreted as a 
violent Christ, first in the Gospels as rhetorically violent and eventually in Revelation as physically violent.

As the $Q$ community ( $Q$ for Quelle, as a source of Jesus' sayings) and the community of Matthew faced fellow Jews who did not accept Jesus as Messiah, they not only called their opponents 'rude names' and debased them with 'derogatory stereotypes' (Crossan 2015:173), probably receiving the same from their opponents, but they also put those invectives on their Jesus' lips. Thus Q's Jesus condemns those fellow Jews to hell on the apocalyptic day of judgement, which Matthew intensifies by adding as a refrain 'where there will be weeping and gnashing of teeth' and calling his Pharisaic opponents 'hypocrites', 'blind guides', 'blind fools' and 'snakes or vipers' - quite different from the Jesus that Matthew presents earlier as giving a sermon on a mount forbidding precisely such 'anger, insult, and name-calling', a presentation of Jesus much closer to the non-violent historical Jesus (Crossan 2015:178). In the gospel of John, the verbal abuse reaches its climax when its Jesus demonises those Jews who would not accept him as messiah by telling them that they are children of the devil, following their father the devil's desires (Jn 8:44).

In Revelation, the non-violent Jesus is fully turned into a physically violent Christ. Before reaching earth's final perfect transformation and as the means of reaching it, Christ is portrayed as a warrior on a battle horse fighting the Roman Empire, with blood up to the horse's bridle and blood flowing for about 200 miles, that is about 300 kilometres ( $\operatorname{Rv} 14: 20)-$ 'a violence far more overwhelming than anything Rome ... [could] muster' (Crossan 2015:185), quite different from the Jesus of the sermon on the mount and Jesus' symbolic peaceful entrance into Jerusalem on a donkey. Before the final wedding feast with the new Jerusalem coming down to earth from God, another feast is imagined in which vultures will feast on the corpses of the mighty and all humanity. "The slaughtered Lamb has become the slaughtering Lamb' (Crossan 2015:180). Revelation is filled with metaphors that promise actual, physical violence of war and conquest against Rome. Revelation creates for Crossan (2015:181) an apocalyptic vision of 'a bloodthirsty God and a blooddrenched Christ' that negated the non-violent message and project of the historical Jesus - 'Revelation's worst libel against God and worst slander against Jesus', in Crossan's (2015:185) judgement.

\section{Violence and non-violence in Paul}

What happened to the historical Jesus also happened to Paul - both were turned into their opposites. Crossan argues that the historical Paul's vision and programme in the capital cities of the Roman provinces was basically in continuity with that of Jesus in the Galilean villages, each using language appropriate to his respective rural and urban context. Jesus used parables and aphorisms to make clear to his rural audience the meaning of God's rule versus that of Rome, and his kingdom movement implemented that vision of nonviolent distributive justice within those villages. Paul used titles such as 'Son of God', 'God' and 'Saviour' for Jesus in deliberate opposition to those same titles that were used for the emperor in the Greek East of the Roman Empire to justify hierarchies of conqueror over conquered, men over women and free over slaves. In his letter to the Galatians, Paul negated those hierarchies by insisting on egalitarian practices within his house churches, where 'there is no longer Jew or Greek, there is no longer slave or free, there is no longer male and female' (G13:28). Thus women play important leadership roles in the Pauline communities (e.g. Phoebe, Junia and Prisca) and, in his letter to Philemon, Paul appeals to this slave owner to free his slave Onesimus, who under Paul converted to Christianity.

However, sadly, Paul's egalitarian vision and programme of no hierarchies of class, gender and ethnicity in his house churches around the middle of the 1st century was again reversed by the end of that century. In the Deutero-Pauline letters of Colossians and Ephesians, and finally in the antiPauline Pastoral epistles, the hierarchies of imperial Rome became re-established, preparing the way for Constantine's empire. Thus the letter to Titus by the end of the 1st century assumes the normalcy of Roman slavery and instructs Christian slave-owners: 'Tell slaves to be submissive to their masters and to give satisfaction in every respect; they are not to talk back, not to pilfer, but to show complete and perfect fidelity' (Tt 2:9-10, in Crossan 2015:223). Similarly, 1 Timothy, contrary to the historical Paul, promotes the subordination of women to men in Christian congregations: 'Let a woman learn in silence with full submission. I permit no woman to teach or to have authority over a man' (1 Tm $2: 11,12)$. No female leaders are allowed here, only married males with children as Christian leaders, as these antiPauline letters elsewhere instruct their audience (cf $1 \mathrm{Tm}$ 3:2, 4, 12; 4:1-5; Titus 1:5-6; in Crossan 2015:228-229) - a patriarchal programme that was, however, challenged by ascetic Christian women as evidenced in the Acts of Thecla at the beginning of the 2 nd century.

We may challenge Crossan on his historical-critical exegesis of specific texts. We may particularly wish to further problematise his constructs of the historical Jesus and Paul and his taking of them as normative. In the following reflection I will, however, not take this route, but instead consider whether Chidester's mapping of definitions of the key concept of 'violence' and Mack's critical application of Girard's theory of violence might afford us a lens to look anew at Crossan's analysis of violence in the Christian Bible.

\section{'Violence' as a key analytical concept \\ Chidester's mapping of 'violence' as an analytical concept}

Chidester's (1991:x-xiii, 2012:55-67) conceptualisation of 'violence' proceeds in three steps, from mapping philosophical definitions of 'violence', through definitions of 'political violence', to anthropological analyses of the role of religion in political violence. 
In reviewing philosophical definitions of 'violence', Chidester (1991:x-xiii, 2012:55-57) identifies and plots four possible conceptualisations of 'violence' on a graph:

- In terms of scope, on the vertical axis, a minimalist definition conceptualises violence as direct physical harm to persons or property, whereas a maximalist definition sees violence as the systemic or institutionalised violation of human dignity. The advantage of a minimalist definition is that it allows precise measurement of harm done to persons and property: one can specify on a scale the degree of injury to or death of persons and quantify the extent of damage to and destruction of property. Presupposed in assessing the degree of harm done to persons or property, however, is a normative sense of human well-being. The maximalist definition thus broadens our understanding of 'violence' by focusing on structures of social injustice that psychologically and socially dehumanise people or violate their dignity as human beings.

- In terms of ethics, on the horizontal axis, one may place at one extreme a definition that judges violence as direct, physical harm, as a destructive force that is always ethically unacceptable, and at the other extreme a definition that holds that violence as direct, physical harm may in certain circumstances be ethically justified as legitimate means to a just end.

The question of the ethics of violence becomes pronounced when we consider definitions and theories of 'political violence'. In reviewing definitions of 'political violence', Chidester (2012:57-61) finds the above four definitions again pertinent as framework:

- In terms of scope, on the vertical axis, a minimalist definition of political violence conceptualises political violence as collective acts of political significance that result in direct physical harm to persons or property. Again the advantage of a minimalist definition is that it allows for quantification of the harm done to persons and property: one can count the number of dead and injured; quantify the extent of damage to property caused by direct, physical political violence; or express the intensity of the direct, physical political violence on a scale from no violence to war. However, by assuming that a zero level of political violence is desirable and that political violence is abnormal, such a scale reinforces the ethical legitimacy of a political status quo.

A maximalist definition of violence as the systemic or institutionalised violation of human dignity recognises the normalcy of political violence for the modern state. The state, according to Max Weber, holds by definition a monopoly on violence, claiming and reserving for itself the sole right to legitimately use violence. Marxists theorise the state as a violent system with one class oppressing and exploiting another to maintain order. Johan Galtung, too, considers the political violence of domination and social injustice to be inherent in state structures, influencing human beings to such an extent that they are less than what they can be. In Galtung's view, political violence can thus never be conceived as neutral and innocent.
- Reflecting further on ethics, on the horisontal axis, political violence as direct, physical harm to persons or property may either be considered always illegitimate or in some cases as legitimate. The first view, held by functionalist theorists, assumes that a normal society is in a state of equilibrium and considers any act of direct physical political violence to be an illegitimate disruption of social order. ${ }^{11}$ Some functionalists argue that political violence may actually reinforce the status quo, when established authority accommodates the demands of violent protesters. The sole legitimacy of the established order is here still assumed, and any violence from political opponents is considered illegitimate.

The second view, however, argues that violent resistance can be ethically justified, if it serves a higher purpose of liberation from unjust systemic oppression. For Hannah Arendt, once we have given up the distinction between their illegitimate violence versus our legitimate force, political theory must deal with the ethical justification of political violence - which it does by appealing to legitimate political ends.

More radical than Arendt are the theories of Georges Sorel and Frantz Fanon, who maintain that violence is not merely an ethically justifiable and legitimate means to liberation but is required as a necessary and legitimate step for the socially and racially oppressed to regain their humanity. It is precisely through violent political action as direct physical harm against oppressors, it is argued, that the socially and racially oppressed can liberate themselves from the dehumanising systemic violence of class exploitation and colonial oppression.

In conceptualising 'religious violence' as embedded in social-political contexts, ${ }^{12}$ Chidester (2012:61-67) argues that anthropological analyses of the role of religion in political violence help us to get closer to the often-violent struggle of people to be human in the actual everyday world, in a specific place and time. An anthropology of violence attends not only to myths and rituals that are constructed and employed to normalise a particular world view that classifies persons and orientates them in time and place, but also to myths and rituals that contest such world views and offer alternatives.

Within the South African context of apartheid in the 1980s, for example, two sacred nationalisms contested each other violently for power and meaning before a settlement was negotiated in the early 1990s. On the one hand, although the apartheid state had previously been legitimised by the Dutch Reformed Church's world view of Christian nationalism, by the 1980s it created its own religion of apartheid myths, rituals and institutions (parliament, laws, military, police and schools) through which it expressed, legitimated and normalised its violent world view of racial classification of a white minority as racially superior and the majority of black people as inferior and even subhuman.

11.An example would be the apartheid state calling its violence legitimate to maintain law and order, and the violence of its opponents illegitimate.

12.Cf. again footnote 4 above on the concept of religion. 
Chidester (2012:62-63) argues that the right-wing Afrikaner nationalist Barend Strydom's 1988 killing of black people on Pretoria's Strijdom Square may be analysed as a ritual that he intended as the sacrifice of a number of black people to his Afrikaner nationalist God, to purify South Africa from blacks and reinforce the power of his exclusionary right-wing world view of white Afrikaner Christian nationalists against the African National Congress (ANC). Strydom's violent ritual of enacting direct, physical harm on black people was a symptom of apartheid's normalised exclusionary religious nationalist world view of systemic political violence that dehumanised black people as different from and inferior to whites.

In contrast, in the anti-apartheid struggle, the ANC in the 1980s created and deployed its own myths and rituals of armed liberation to oppose the psychological and social suffering of black people and to give meaning to its alternative world view with its classification of black people as human beings with equal dignity to whites. These violent acts themselves, Chidester (2012:67) states with reference to Fanon, could be seen as serving a sacred liberating function in helping black people to recover their humanity.

\section{A comparison of Crossan and Chidester's conceptualisation of 'violence'}

How does Crossan's conceptualisation of 'violence' compare with that of Chidester? In How to read the Bible and still be a Christian, Crossan (2015) does not dwell on definitions of 'violence'. We may, however, get a sense of his understanding of this key term by paying close attention to his text.

A bit more than two-thirds through the book, Crossan (2015:173) conceives of three steps in the escalation of human violence, 'from ideological through rhetorical to physical violence':

- He defines ideological violence as the judgement of 'certain others to be inhuman, subhuman, and lacking in one's own humanity'.

- Rhetorical violence is an escalation of ideological violence, since by presuming the ideological dehumanisation of others, it proceeds to debase them 'with rude names, crude caricatures, and derogatory stereotypes or by excluding them as political "traitors" or religious "heretics"".

- Physical violence, which may end in death, presupposes the previous two steps and may either be an illegal attack or, 'if one has attained social power', an official, legal, political act.

Crossan (2015:173-185) then proceeds in this chapter on 'Christ and the normalcy of civilisation' to apply the above conceptual framework to argue that a non-violent historical Jesus came to be reinterpreted as a rhetorically violent figure in the Gospels and finally as a physically violent figure in Revelation - a development that reinterpreted the historical Jesus to conform to the violent values of the Roman Empire.
It may then be the case that Crossan's distinction between three steps in the escalation of violence derives more from his reading of the New Testament than from any philosophical or political definitions in academic literature. More helpful, however, would be an appreciation of Crossan's anthropological analysis of violent and non-violent myths and rituals of the Roman Empire, its supporters and opponents - the historical case study that has occupied most of his scholarly work.

Juxtaposing Chidester's outline of philosophical definitions of violence, definitions of political violence and anthropological studies of violence with Crossan's analysis of violence in the Jesus movement and early Christianities within their Roman imperial context may help us to clarify and specify the concept of 'violence' in the following ways:

- In a maximalist sense, 'violence', more specifically maximalist 'political violence', refers to politicaleconomic systems that violate human dignity. Those in power construct myths, rituals and institutions that legitimise and normalise the structural inequalities of domination and exploitation, and the dehumanising classification of persons - aspects that are analysed in anthropological studies of violence. Chidester $(1991,2012)$ examines the apartheid system as a case in point. Crossan (2015), in this maximalist sense of the term, would consider the ancient empires of Assyria, Babylonia, Persia, Greece and Rome, as well as the contemporary USA empire, as examples of such institutionalised violence.

- In a minimalist sense 'violence', more specifically minimalist 'political violence', refers to collective political action that causes direct, physical harm to people and property. It may range from injuring to killing people, from uprisings to war. For Chidester $(1991,2012)$ the apartheid state with its military and police forces (the right-wing Afrikaner nationalist Barend Strydom's killing of black people was a symptom of apartheid's world view with its legitimising myths and rituals), as well as the ANC's military resistance, exemplified violence in this sense. Crossan's (2015) empires listed above would all engage in violence as physical harm through its military and police forces, but one would also need to include 1st-century forms of armed resistance that Crossan in each case analyses with due attention to its particular legitimising myths and rituals. Crossan (2015) uses the phrases 'the normalcy of civilisation' and 'civilisation's drug of choice', sometimes to refer to violence in the maximalist and sometimes to refer to violence in the minimalist sense. ${ }^{13}$

- More contested is an ethical judgement of violence in the minimalist sense. Can violent acts of political significance that physically injure or kill persons and damage or destroy property be ethically justified? If one follows

13.For 'the normalcy of civilisation', see e.g. Crossan $(2015: 31,33,34,37,135$, 137 $185,201,215,220,233,238,240$ ). For 'civilisation's drug of choice', see e.g. Crossan (2015:67, 71, 244), where the phrase is used to refer to 'escalatory violence'. Cf. Strijdom (2015) for a discussion on the patriarchal family as a mode for conservative politics (embodying systemic violence) and the egalitarian family as a model of liberal politics, in debate with Crossan's analysis of early Christianities and the Roman empire. 
Crossan's (2015) argument, there is no way that violence in this sense can ever be ethically condoned by Christians, if they take his construct of a non-violent Jesus as normative. This kind of violence must indeed be condemned as morally unacceptable, not only when the violence is physically enacted by those in power or the oppressed, but also when it is rhetorically articulated or even imagined in fantasies of revenge. (He argues in his earlier work that Jewish-Christian apocalyptic mentalities are particularly prone to imagine revenge by $\mathrm{God},{ }^{14}$ which he considers negatively not only because they 'affect the human heart', but also because they may inspire followers to take up arms themselves). ${ }^{15}$ However, Chidester (2012) challenges us to consider in more depth the question of the ethics of violence by engaging with critical theorists such as Arendt and Fanon. Although Arendt is said to have confronted us with the challenge to think about the justification of political violence once we have dispensed of the distinction between their violence and our violence, it is Fanon who confronts us more radically with the possibility of considering violent acts by the oppressed as a necessary condition for their liberation and the recovery of their humanity under colonial conditions. For Crossan, taking his historical Jesus as the norm, social transformation under conditions of systemic injustice should be brought about in a nonviolent way. That is the only ethical way for Crossan. For Fanon and his followers, however, violent resistance under conditions of colonial oppression is an ethically justifiable way to bring about individual healing and social change. It is the latter argument within postcolonial discourses that is not engaged in Crossan's work and that would in my view enhance his analysis.

The second point that we turn to concerns the extent to which Crossan engages with theories of violence. Is there a way to get further than Crossan's psychological statement that

14.Cf. Strijdom (1998:54-93) for a discussion of Crossan's typology of violent and nonviolent forms of resistance, including forms of resistance by upper- and lower-class pre-70 CE Jewish millennialists who imagined the violent intervention of God through a violent royal messiah of Davidic descent or a violent heavenly figure (e.g. in the Similitudes of Enoch and the Qumran scrolls).

15.In his major work on the historical Jesus, Crossan (1991) concluded that the historical Jesus' kingdom vision and grassroots programme of egalitarianism in rural Galilee was not apocalyptic. He expressed his ambivalent judgment of apocalyptic visions:

it is surely proper to mourn rather than mock those visions of a perfect world so deeply embedded in the human heart as to appear again and again, ever defeated and ever repeated. At their best they kept alive a hope for perfect justice within which smaller gains might be achieved as means and methods, strategies and tactics were slowly and painfully learned. At their worst they seduced people into believing that means and methods, strategies and tactics were no longer necessary (Crossan 1991:108).

In his major work on the earliest non-Pauline Christian movements, it is particularly the violent type of apocalypticism that Crossan (1998:283) finds disturbing. It not only expects God to intervene violently with or without the collaboration of humans, but 'too often [involves] ... a divine vengeance that results in human slaughter. ... [It] almost inevitably presumes a violent God who establishes the justice of nonviolence through the injustice of violence'. Crossan (1991:283) continues with his assessment:

That may well be understandable in particular human circumstances. That may well be understandable when a genocide of them from above is invoked to prevent their genocide of us here below. But all too often, be it of pagans by Jews or of Jews by Christians, apocalypticism is perceived as a divine ethnic cleansing whose genocidal heart presumes a violent God of revenge rather than nonviolent God of justice.

Crossan's (2015:3) aversion to violence as seated in the human heart is probably best captured in the quotation from Yeats with which he opens his book: 'We had fed the heart on fantasies,/The heart's grown brutal from the fare'. I argue below that the application of social or social-psychological theories of violence (e.g. that of Girard) may take us a step further in understanding violence. violence is seated 'deep in the human heart' and to move in our understanding beyond his ethical choice between good (non-violence) and bad (violence)? An engagement with theories of violence from Weber, Marx, Galtung, Arendt, Fanon or Bataille may indeed help us. I give one example of another scholar of early Christianity, Burton Mack, to show how his critical engagement with René Girard's socialpsychological theory of violence offers us one possibility to analyse violence in early Christian texts. ${ }^{16}$

\section{A comparison of Mack's application of Girard's theory of violence with Crossan's analysis of violence}

In his sociological critique of early Christian myths, Burton Mack (1985, 1987, 1988, 1989, 1995, 2008a, 2008b) has focused on the dangerous influence that these mental constructs that were constructed by and in the interest of early Christian social formations have exerted on the Western imagination and politics, from colonial missionary projects up to American exceptionalism. ${ }^{17}$ At the basis of these myths, rituals and institutions, Mack argues, lies a binary hierarchy that has legitimised the superiority of the West over others - a mentality that cannot be ethically justified in our times but should be replaced by postmodern attitudes and practices of multicultural respect and fair dialogue. Mack critically analyses early Christian myths as social formations, including the scapegoating of Jews in the Gospels, the dangerous construct of an apocalyptic myth that presented its own group as pure, innocent, exceptional and powerful but demonised others, and the Christian canon as a pitiful reduction of diversity. I focus here on his critical engagement with René Girard's theory of violence to interpret the victimisation of Jews in the Gospels and the legacy of early Christian scapegoating in Western history (cf. Strijdom 1997).

On the basis of his reading of Western literature, Freud and historical studies of religion, Girard (1977, 1986; cf. also Mack 1987) developed a general social-psychological theory of violence. Violence, one may deduce, is primarily understood by Girard in the sense of physical harm to persons and animals. According to this theory, violence lies at the very heart of social formation. By redirecting the aggression that is acquired by mimetic learning away from itself onto a common scapegoat, the formation of a group and culture becomes possible. It is this harsh dynamic of victimisation that his critical analysis claims to expose behind blood sacrifices and, extrapolating from there, behind war sacrifices of victims, although this reality is mystified by myths that stress the redemptive effect of such sacrifices. This mystification, Girard holds, actually gives the ritual its power. If the critic were to lift the mythical veil and expose the harsh reality behind the ritual to the group, the myth might actually lose its power and lead to the destruction of

16.In a recent lecture, after presenting his argument that religion is not more prone to violence than secularism, Cavanaugh (2016) answered a question on how he would explain violence, once the binary of religious and secular violence is dismantled, by explain violence, once the binary of religious and sect
pointing to Girard's theory as a helpful possibility.

17.Cf. Strijdom (2009) for a discussion of Mack's critique of the influence of the binary hierarchical logic of the Christian myth on the construct of the notion of the USA as an exceptional Christian nation. 
the group. The Christian gospel, Girard concludes, offers a solution to this dilemma. By exposing violence as social injustice from the perspective of innocent victims, it opens the ethical possibility of peaceful social coexistence. Girard thus considers it his ethical duty to expose, in line with the Christian gospel, the victimisation of innocent groups by those in power in order to challenge the dynamics of scapegoating in the formation of groups and to offer a morally justifiable alternative.

Mack challenges Girard's proposal that the Christian gospel offers a solution to the problem of violence. Instead of offering a solution to the mechanism of scapegoating behind group formation, these early Christian groups regrettably enacted it. Not only did they, as a subcultural and marginalised minority, direct their anger towards Jews for rejecting Jesus as the Messiah, but they even more dangerously veiled this by creating an apocalyptic myth that portrayed their own hero and themselves as innocent victims of their Jewish opponents. The destruction of the Temple in $70 \mathrm{CE}$ was interpreted by the Gospel of Mark as a sign of their God's just punishment of Jewish disobedience, and they imagined in their apocalyptic fantasies that God's condemnation of their enemies would in the near future be consummated, whilst they themselves would be vindicated by God. This victimisation of Jews by Christians masked by a myth of their own innocence and power effected a 'long, ugly history':

... through the adversus Judaeos literature, to the crusades, reactions to the plagues, Catholic doctrine, Luther's pronouncements, German tracts of the nineteenth and early twentieth centuries, common clichés in New Testament scholarship, and the anomaly of anti-Semitic attitudes that emerge throughout the third world wherever the gospel is read today (Mack 1988:375).

He concludes by saying that 'the Nazi enactment of the final solution may have been tainted by pagan desires. But the rationale was Christian' (Mack 1988:375).

A peaceful solution to the dynamics of violence, according to Mack, lies not in the Christian gospel, but in exposing the mechanism of scapegoating from the perspective of the Jews as victims and in abolishing the myth of an innocent group with power. In our time, this myth of innocence combined with extraordinary power is most clearly embodied in the myth that the USA as an exceptional Christian nation is justified to save the world by violent intervention - a mythic mentality that is reflected in popular USA narratives of 'a captain with a gun, zapping resident aliens that obstruct his vision' (Mack 1989:5), whether in the Lone Ranger, Superman or Star Trek. The future of the world, Mack concludes, cannot lie with this myth of innocence and power. Instead, in order to construct peace in our postmodern world, he argues, we need to cultivate multicultural dialogue that not only recognises that there are no pure, faultless messiahs but importantly promotes tolerance and values cultural diversity: 'the world is ... a richly woven tapestry, interesting and elegant precisely because of its many patterns, worthy of its wisdoms' (Mack 1988:373).
Although Crossan (2015:173-185), as we saw above, ${ }^{18}$ traced and condemned the escalatory violence against Jews, from an initial intra-Jewish conflict in the gospels to eventual antiSemitism, with special attention to Oberammergau and its appropriation by Hitler, he has not engaged at any length with a theory of violence. Mack, I hold, has shown us a way in which looking at violence through Girard's theoretical lens may throw new light on the problem of violence.

\section{Conclusion}

What have we achieved in this contribution? I have argued that Crossan's historical-critical analysis of violence in the Christian Bible may be refined and taken further in two overlapping ways. Firstly, a clarification of the concept of 'violence' is needed for analytical purposes. When does one use it in a maximalist sense to refer to systemic injustice, and when does one employ it in a minimalist sense to refer to physical harm to persons or property? Furthermore, does one always condemn violence in the minimalist sense (whether enacted by those in power or by protesters) or does one consider this kind of minimalist violence, when enacted by oppressed and marginalised people, to be ethically justifiable under certain conditions? In both instances an anthropological analysis of myths and rituals that justify the type of violence within specific contexts is instructive. Crossan and Chidester surely do this kind of contextual analysis of myths and rituals that legitimise violence in exemplary fashion.

Secondly, how may theories that elaborate the concept of 'violence' provide us with a lens to analyse violence in the Christian Bible? I argued that Mack's critical use of Girard's socialpsychological theory of violence may assist us to understand violence more profoundly than merely locating its presence 'honestly'19 in the Christian Bible and psychologically 'deep in the human heart'.

In conclusion, as a prompt to further thinking, I underline the fact that decolonial and critical race theorists challenge us on two fronts: on the one hand they insist that we seriously argue about the legitimacy of violent resistance under conditions of systemic oppression (Fanon being a major point of reference), ${ }^{20}$ but on the other hand they also insist that we seriously rethink liberal and postmodern discourses that hold that the education of multicultural citizens would contribute to a more just and peaceful world. Some persuasions are simply, from the perspective of the racially and economically oppressed, these critics hold, not ethically justifiable and do not deserve to be included or accommodated. The sociologist Ellen Berrey (2015), for

18.Crossan (1996) traced this trajectory in much more detail in his earlier book who killed Jesus?: Exposing the roots of anti-Semitism in the gospel story of the death of Jesus.

19. Crossan $(2015: 31,79,98,118,138,171)$ considers it 'honest' of the Christian Bible to have included both violent and non-violent views of God, Jesus and humans.

20.Pithouse (2016) contests the view that Fanon endorsed violence by the oppressed against French colonialism in Algeria and argues that the view that Fanon considered 'the anti-colonial struggle as simply a violent clash between two absolutes' derives from Sartre rather than Fanon. Chidester (2012:60) bases his interpretation of Fanon, in my view convincingly, on specific statements from Fanon's (1968) The wretched of the earth. 
example, argues that the rhetoric of multiculturalism may serve to preserve white privilege and that the word tends to be used by liberal white people who are too uncomfortable to speak about race. In South Africa too, now in 2016, the ideal of a rainbow nation is on trial, as a recent documentary captures our current need to again address, as a matter of urgency, the problem of race..$^{21}$

\section{Acknowledgements Competing interests}

The author declares that he has no financial or personal relationships which may have inappropriately influenced him in writing this article.

\section{References}

Berrey, E., 2015, 'Diversity is for white people: The big lie behind a well-intended word', Salon 26 October 2015, viewed 22 April 2016, from http://www.salon. com/2015/10/26/diversity_is_for_white_people_the_big_lie_behind_a_well_ intended_word/

Braun, W. \& McCutcheon, R. (eds.), 2000, Guide to the study of religion, Cassell, London.

Cavanaugh, W., 2016, 'Does religion cause violence?', Studium generale lecture University of Groningen, viewed 16 April 2016, from https://streaming3.service. University of Groningen, viewed 16 April
rug.nl/p2gplayer/Player.aspx?id=bJGqFY

Chidester, D., 1988, 'Religion alive/religious studies unborn? Review article about recent research on African indigenous churches', Journal for the Study of Religion $1(2), 83-94$

Chidester, D., 1991, Shots in the streets: Violence and religion in South Africa, Oxford University Press, Cape Town.

Chidester, D., 1996, Savage systems: Colonialism and comparative religion in southern Africa, University Press of Virginia, Charlottenville, VA.

Chidester, D., 2000a, 'Colonialism', in W. Braun \& R. McCutcheon (eds.), Guide to the study of religion, Cassell, London.

Chidester, D., 2000b, 'Material terms for the study of religion', Journal of the American Academy of Religion 68(2), 367-379. http://dx.doi.org/10.1093/jaarel/68.2.367

Chidester, D., 2012, Wild religion: Tracking the sacred in South Africa, University of California Press, Berkeley, CA.

Chidester, D., 2013, 'Postgraduates producing knowledge', Journal for the Study of Religion 26(1), 5-7.

Chidester, D., 2014, Empire of religion: Imperialism and comparative religion, University of Chicago Press, Chicago, IL.

Crossan, J., 1991, The historical Jesus: The life of a Mediterranean Jewish peasant, T\&T Clark, Edinburgh.

Crossan, J., 1996, Who killed Jesus?: Exposing the roots of anti-Semitism in the gospel story of the death of Jesus, HarperCollins, San Francisco, CA.

Crossan, J., 1998, The birth of Christianity: Discovering what happened in the years immediately after the execution of Jesus, HarperCollins, New York.

21. For the documentary The people versus the rainbow nation, see 'South Africa's rainbow nation on trial' at http://www.timeslive.co.za/entertainment/2016/04/20/ WATCH-South-Africa\%E2\%80\%99s-rainbow-nation-on-trial (viewed 22 April 2016).
Crossan, J., 2015, How to read the Bible and still be a Christian: Struggling with divine violence from genesis through revelation, Harper Collins, New York.

Fanon, F., 1968, The wretched of the earth, Grove Press, New York.

Girard, R., [1972] 1977, Violence and the sacred, Johns Hopkins University Press, Baltimore, MD.

Girard, R., [1982] 1986, The scapegoat, Johns Hopkins University Press, Baltimore, MD.

Mack, B., 1985, 'The innocent transgressor: Jesus in early Christian myth and history', René Girard and Biblical Studies, Semeia 33, 135-165.

Mack, B., 1987, 'Introduction: Religion and ritual', in R. Hamerton-Kelly (ed.), Violent origins: Ritual killing and cultural formation, pp. 1-72, Stanford University Press, Stanford, CA.

Mack, B., 1988, A myth of innocence: Mark and Christian origins, Fortress, Philadelphia, PA.

Mack, B., 1989, Innocence and power in the Christian imagination, Institute for Antiquity and Christianity, Claremont, CA.

Mack, B., 1995, Who wrote the New Testament? The making of the Christian myth Harper, San Francisco, CA.

Mack, B., 2008a, Myth and the Christian nation: A social theory of religion, Equinox, London.

Mack, B., 2008b, 'Sacred persistence', in W. Braun \& R. McCutcheon (eds.), Introducing religion: Essays in honor of Jonathan Z. Smith, pp. 296-310, Equinox, London.

Morgan, D. (ed.), 2008, Key words in religion, media and culture, Routledge, New York.

Pithouse, R., 2016, 'Violence: What Fanon really said', Mail \& Guardian, 08 April 2016, viewed 12 April 2016, from http://mg.co.za/article/2016-04-07-violence-whatfanon-really-said

Plate, B. (ed.), 2015, Key terms in material religion, Bloomsbury, London.

Rollens, S., 2013, 'The rewards of redescription: An assessment of Burton Mack's influence on the study of Christian origins', in A. Hughes (ed.), Theory and method in the study of religion: Twenty five years on, pp. 171-176, Brill, Leiden.

Sanchez, D., 2015, 'Review essay roundtable: A myth of innocence: Mark and Christian origins. By Burton L. Mack. Fortress Press, 1988', Journal of the American Academy of Religion 83(3), 826-857.

Segal, R. \& Von Stuckrad, K. (eds.), 2015, Vocabulary for the study of religion, Brill, Leiden.

Smith, J.Z., 1995, 'Emic/etic', in J.Z. Smith (ed.), The HarperCollins dictionary of religion, HarperSanFrancisco, New York.

Smith, J.Z., 2000, 'Classification', in W. Braun \& R. McCutcheon (eds.), Guide to the study of religion, pp. 35-44, Cassell, London.

Smith, J.Z., [1999] 2004a, 'Bible and religion', in J.Z. Smith, Relating religion: Essays in the study of religion, pp. 197-214, University of Chicago Press, Chicago, IL.

Smith, J.Z., [1998] 2004b, 'Religion, religions, religious', in J.Z. Smith (ed.), 2004, Relating religion: Essays in the study of religion, pp. 179-196, University of Chicago Press, Chicago, IL.

Smith, J.Z., 2009, 'Religion and Bible', Journal of Biblical Literature 128(1), 5-27. http://dx.doi.org/10.2307/25610162

Strijdom, J., 1997, 'Teologieë as gevaarlike mensemaaksels: Burton Mack se evaluasie van vroeg-Christelike mites', Hervormde Teologiese Studies 53(3), 609-622. http://dx.doi.org/10.4102/hts.v53i3.1672

Strijdom, J., 1998, 'An evaluation of John Dominic Crossan's construct of the historical Jesus: The Baptist as test case', Unpublished DD-thesis, University of Pretoria.

Strijdom, J., 2009, 'Nationalising religion: The violent path of religious nationalism', Alternation Special Edition 3, 254-269.

Strijdom, J., 2015, 'Conservative and liberal, hierarchical and egalitarian: Socialpolitical uses of the concept of "home" in Greco-Roman antiquity and early Christianity', Phronimon 16(1), 29-38.

Taylor, M. (ed.), 1998, Critical terms for religious studies, University of Chicago Press, Chicago, IL. 